\title{
MUDANÇAS CURRICULARES E QUALIDADE DE ENSINO: ENSINO COM PESQUISA COMO PROPOSTA METODOLÓGICA PARA A FORMAÇÃO DE CONTADORES GLOBALIZADOS
}

\section{CURRICULUM CHANGE AND QUALITY OF TEACHING: RESEARCH IN TEACHING AS A METHODOLOGICAL PROPOSAL FOR THE EDUCATION OF THE GLOBAL-SCALE ACCOUNTANT}

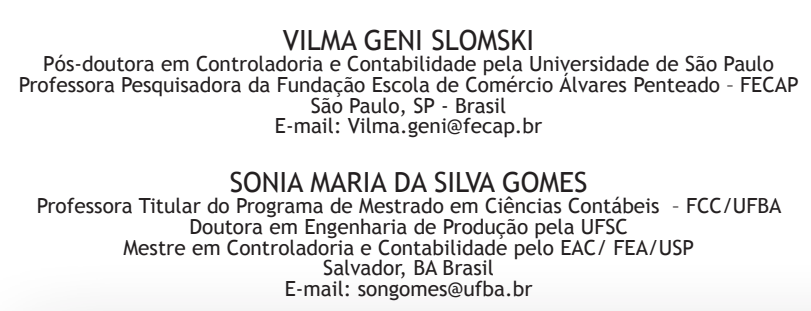

VILMA GENI SLOMSKI

Fundação Escola de Comércio Álvares Penteado - FECAP

E-mail: Vilma.geni@fecap.br

Resumo

Este artigo tem como objetivo aprofundar as discussões e ressaltar o debate em torno das mudancas curriculares e da qualidade do ensino na universidade, procurando identificar e apontar o modelo e a prática curricular capaz de orientar o trabalho educativo na área Contábil, com vistas a possibilitar aprendizagens significativas em sala de aula e, assim, atender às reais necessidades dos alunos em consonância com as exigências sociais e educacionais contemporâneas. Para tanto, desenvolveu-se um ensaio teórico, no qual foram analisados e discutidos estudos e pesquisas como os de Latorre e Gonzáles (1992), Moraes, 1996; Demo, 1997; Cunha, 1998; Assmann, 2001; Libâneo, 2001; Chauí, 2001; Fazenda, 2002; Mazetto, 2003; Morin, 2001; 2005; Sousa Santos, 2006; Lampert, 2008; Dias Sobrinho, 2008; 2009 e outros, que analisam, criticamente, o atual modelo de universidade e sua organizacão curricular e, como contraponto, esses autores defendem a construção coletiva do Projeto Político Pedagógico, o currículo globalizado e a adoção do princípio metodólógico do ensino com pesquisa como o modelo mais adequado para a formação científica e tecnológica dos alunos. Verificou-se que as mudanças curriculares atuais conclamam, cada vez mais, que as ações dos alunos se deem a partir de e sobre a realidade, tanto experiencial cotidiana quanto referente ao futuro exercício profissional, evidenciando a indissociabilidade entre ensino e investigacão como princípio didático mais adequado para por em prática o dispositivo legal vigente que sinaliza as competências e habilidades que os profissionais devem possuir para o exercício de suas atividades. Aprender com pesquisa é um processo dialógico e desafiador que envolve a problematização do conhecimento, a construção de argumentos e sua respectiva validação. Conclui-se, assim, que o ensino pela pesquisa busca a excelência e a inovação no ensino superior tendo a apropriação e producão do conhecimento científico como condição para viver na sociedade aprendente e enfrentar os desáfios da modernidade.

Palavras - chave: Mudanças curriculares ; Projeto Político Pedagógico ; Ensino com pesquisa; Qualidade de ensino; Contadores globalizados.

\begin{abstract}
The aim of this article is to intensify the discussion and highlight the debate on curricular changes and the quality of teaching in the Universities, aiming to identify and point out the curricular model and practice capable of directing the educational work in the area of Accounting, seeking to make significant learning happen in the classroom, and, this way meeting the real necessities of students as far as current social and educational demands go. To do so, a theoretical essay was developed analyzing and discussing studies and research such as the ones by Latorre and Gonzáles (1992), Moraes, 1996; Demo, 1997; Cunha, 1998; Assmann, 2001; Libâneo, 2001; Chauí, 2001; Fazenda, 2002; Mazetto, 2003; Morin 2001; 2005; Sousa Santos, 2006; Lampert, 2008; Dias Sobrinho, 2008; 2009 , and others who critically analyze the present model of university and its resulting curricular organization; as a counter argumentation, these authors support the collective construction of the Political and Educational Project; globalized curricula; and the implementation of the methodological principle of teaching tied to research as the most appropriate model to develop the scientific and technological education of students. It was possible to notice that the current curricular changes have demanded that the actions taken by students be based on and upon reality more and more, in relation to both, daily experience, and the future actions in the professional world. This emphasizes the relatedness between teaching and research as the educational principle best suited for putting into practice the current legal mechanism that portrays the competence and abilities professionals must bear when performing in their careers. Learning tied to research is a dialogic and challenging process that involves looking for ways through knowledge, as well as building arguments and their validation. It is thus possible to conclude that teaching through research aims not only at excellence, but also at the ground-breaking in university education, where taking hold and producing scientific knowledge are the conditions to live in a learning society and to face the challenges of modern times.
\end{abstract}

Key-words: Curricular Changes; Political and Educational Project; Teaching tied to research; Quality of teaching; Global-scale accountants.

Enviado em: 14/12/2009 - Aceito em: 23/05/2010 -2a revisão: 01/07/2010

Artigo aceito no $7 m o$ Congresso Internacional de Educação Superior - UNIVERSIDADE 2010- Havana/Cuba.

RCO - Revista de Contabilidade e Organizações - FEA-RP/USP, v. 4, n. 8, p. 160-188, jan-abr 2010. 


\section{INTRODUÇÃO}

Os "hiperespecialistas" são pretensos conhecedores, mas de fato praticantes de uma inteligência cega, posto que parcelar e abstrata, evitando a globalidade e a contextualização dos problemas (EDGAR MORIN, 2005)

As formas tradicionais de conceber o conhecimento vêm revigorando a discussão sobre currículo e métodos de ensino/aprendizagem, trazendo novas exigências ao debate pedagógico na Universidade. Hargreaves (2004), numa análise sobre a contemporaneidade, diz que a sociedade do conhecimento é uma sociedade de aprendizagem, aprendente. Esse imperativo impõe mudanças na relação homem $x$ conhecimento tendo em vista as novas formas de conceber e de pensar a realidade.

Isso remete aos estudos de Sousa Santos (2006), que identifica o contexto social contemporâneo como um tempo de transição paradigmática entre o moderno (paradigma dominante) e o pós-moderno (paradigma emergente). Como implicações dessa transição, têm-se, de um lado, as certezas e verdades incontestáveis, o conhecimento passível de mensuração e previsibilidade, o dualismo de ideias (certo/errado; bem/mal..); por outro, as dúvidas e incertezas, imprevisibilidade e complexidade. Análise semelhante do contexto atual encontra-se no trabalho de Roza (2005, p.45) que escreve: "este se configura como uma nova percepção de mundo, de homem, de ciência. As verdades absolutas dão lugar ao reino das incertezas; o conhecimento lógico e definido cede lugar ao conhecimento provisório".

Essa realidade perpassa diferentes áreas do saber e atinge, também, os discursos e as práticas pedagógicas que constroem e que constituem o cotidiano da Universidade. Diferentes pesquisas apontam para a necessidade de mudancas curriculares (SAVIANI, 2000, MORAES, 1996, CUNHA, 1998; SOUSA SANTOS, 2006; MORAN, 2001, 2005; FAZENDA, 2002), esses trabalhos ressaltam que "o problema da educação decorre do modelo da ciência que prevalece num certo momento histórico e que influencia as questões epistemológicas e as teorias de aprendizagem das quais derivam a mediação pedagógica e suas práticas correspondentes" (MORAES, 1996, p. $3)$.

A visão dominante de ciência é regida por um rigoroso determinismo, privilegia o "como fazer" em detrimento do "por que fazer". Tal fato conduz à fragmentação e à especialização e, desse modo, ao surgimento de metodologias de ensino que não permitem conflitos cognitivos, percebidos como essenciais às atividades de aprendizagem. Chaves (2007, p. 30) assevera que "os grandes desafios humanísticos, científicos e tecnológicos têm quase sempre caráter interdisciplinar e somente podem ser resolvidos por equipes de profissionais de diversas áreas". Isso significa dizer que para garantir sua empregabilidade, o profissional precisa alargar sua visão de mundo, sem se isolar em especializações que, embora the permitam exercer a profissão, negam-lhe a competência exigida pelo mundo do trabalho global.

Edgar Morin, teórico da complexidade e da interdisciplinaridade, entende que só o pensamento sistêmico sobre uma realidade também complexa faz avançar a reforma do pensamento na direção da contextualização, da articulação e da interdisciplinarização do conhecimento gerado pela humanidade. Para o autor:

[...] a reforma necessária do pensamento é aquela que gera um pensamento do contexto e do complexo. 0 pensamento contextual busca sempre a relação de inseparabilidade e as inter-retroações entre qualquer fenômeno e seu contexto, e deste com o contexto planetário. 0 complexo requer um pensamento que capte relações, inter-relações, implicações mútuas, fenômenos multidimensionais, realidades que são simultaneamente solidárias e conflitivas (como a própria democracia, que é o sistema que se nutre de antagonismos e que, simultaneamente, os regula), que respeite a 
diversidade, ao mesmo tempo que a unidade, um pensamento organizador que conceba a relação recíproca entre todas as partes (MORAN, 2005, p. 23).

Essa mudança paradigmática na forma de conceber o homem e sua relação com o conhecimento tem estimulado reflexões sobre o papel social da universidade nesse novo século. Sua função não é apenas capacitar os acadêmicos para novos postos de trabalho, mas, principalmente, para exercerem com consciência a cidadania, para o que a autonomia, o senso crítico e o desenvolvimento intelectual são pontoschaves no processo de inserção social e profissional. Esse entendimento corrobora a ideia de que a universidade deve zelar pela qualidade do trabalho acadêmico que realiza e pela competência dos profissionais que forma. Assim, deve priorizar o desenvolvimento de competências, habilidades, valores que lhes dêem condições de inserção social e profissional.

Quando se questiona o desempenho do profissional formado pela Universidade é a qualidade do ensino ministrado que concretamente está sendo objeto de avaliação. Esse dado remete à reflexão sobre o papel do docente, sobre a prática de ensino e sobre a construção de um Projeto Pedagógico que concretize os objetivos da Universidade como instituicão social produtora do conhecimento científico e formadora de profissionais competentes a serviço da difusão do conhecimento e do desenvolvimento social (LDB, 1996).

Assim caminha a reforma universitária que, instituída pela LDB (1996), traz orientações governamentais para direcionar o processo de formação humana. A nova Lei, em seu capítulo IV, Art. 43․ I, diz que a finalidade da educação é "estimular a criação cultural e o desenvolvimento do espírito científico e do pensamento reflexivo". Entretanto, o desenvolvimento do pensamento complexo e do pensamento reflexivo exige a superação do currículo tecnicista proposto para a transmissão de conteúdos e desenvolvimento de habilidades a serviço do sistema de producão. A visão unitária e mecanicista do conhecimento no ensino superior produz a realidade histórica dos currículos por disciplinas e o isolamento do corpo docente. Têm sido comum os docentes se enclausurarem em seus laboratórios, em seus problemas de pesquisa, em suas disciplinas com conteúdos descontextulizados a-históricos e pouco ligados à prática social dos alunos.

Para sintonizar a universidade aos paradigmas do mundo moderno e à formação científica e tecnológica dos alunos, a LDB (1996) instituiu a adequação dos cursos de graduação via as Diretrizes Curriculares Nacionais - DCN, que superam os estreitos contornos de currículos mínimos obrigatórios, permitindo uma organização curricular com relativa liberdade e flexibilidade. Após a promulgação da LDB/1996, acompanha-se entre pesquisadores e professores uma forte preocupação na revisão dos processos de ensino e de aprendizagem. Conclama-se, cada vez mais, que as ações dos alunos se deem a partir de e sobre a realidade, tanto experiencial cotidiana quanto referente ao futuro exercício profissional, instalando-se, assim, uma relação de condicionalidade da construção de conhecimentos como determinante para a construção das habilidades e competências sugeridas pelos dispositivos legais.

Pelos processos de interação e apropriação do conhecimento coloca-se o aluno em relação com o produto da ciência, com teorias e tecnologias historicamente desenvolvidas. Nesse processo, o professor desempenha o papel insubstituível de mediação conduzindo os alunos a processos de internalização cada vez mais complexos do acervo científico-cultural e metodológico-técnico necessário para o domínio da realidade da qual faz parte como ser social e sobre a qual irá intervir. Assim sendo, o ensino de qualidade é aquele que promove situações de aprendizagem que possibilitam a construção de conhecimentos/aprendizagens significativas (que ultrapassa o nível da informação apenas) transformado-os em habilidades e competências de atuação profissional. Diante dessa situação, formulou-se a seguinte questão de pesquisa: que 
modelo e prática curricular é capaz de orientar o trabalho educativo na área Contábil com vistas a possibilitar aprendizagens significativas no contexto da sala de aula e, assim, atender às reais necessidades dos alunos em consonância com as exigências sociais e educacionais contemporâneas?

Em vista desse questionamento, elaborou-se como objetivo aprofundar as discussões e ressaltar o debate em torno das mudanças curriculares e da qualidade do ensino na universidade, procurando identificar e apontar o modelo e a prática curriculares capazes de orientar o trabalho educativo na área Contábil com vistas a possibilitar aprendizagens significativas no contexto da sala de aula e, desse modo atender às reais necessidades dos alunos em consonância com as exigências sociais e educacionais contemporâneas.

Para o alcance dos resultados pretendidos, desenvolveu-se um ensaio teórico, o qual consiste na exposição lógico-reflexiva com ênfase na argumentação e interpretação pessoal. Tomou-se como ponto de partida estudos e pesquisas como os de Latorre e Gonzáles (1992), Moraes, 1996; Demo, 1997; Cunha, 1998; Assmann, 2001; Libâneo, 2001; Chauí, 2001; Fazenda, 2002; Mazetto, 2003; Morin, 2005; Sousa Santos, 2006; Lampert, 2008; Dias Sobrinho, 2009 e outros, que analisam, criticamente, o atual modelo de universidade e sua organização curricular consequente e como contraponto, esses autores defendem a construção coletiva do Projeto Político Pedagogico, o currículo globalizado e a adoção do princípio metodológico do ensino com pesquisa como o modelo mais adequado para a formação científica e tecnológica dos alunos.

Considera-se que à medida que estudos e pesquisas se voltam para o esclarecimento dos processos que envolvem o ensinar e o aprender contribuem para a busca da qualidade dos processos educativos e melhoria da qualidade de vida dos que transitam nesse nível de ensino. Nessa direção caminha este artigo, assim, espera-se contribuir para melhorar o entendimento sobre o ensino universitário, os processos de reestruturação e desenvolvimento curricular, bem como a construção coletiva do Projeto Político e, desse modo, o aprimoramento do trabalho pedagógico em termos de métodos, conteúdos, avaliação, situações e ambientes de aprendizagem, tendo em vista o atendimento das necessidades dos alunos e a melhoria da qualidade do ensino universitário.

\title{
2. BUSCANDO A QUALIDADE DA EDUCAÇÃO UNIVERSITÁRIA
}

\begin{abstract}
A escola não deve limitar-se a proporcionar o conhecimento de base disciplinar, antes deve promover aprendizagens que permitam desenvolver competências cognitivas globais necessárias a uma abordagem temática, localizada e integrada dos problemas, estimulando também o trabalho em equipe de especialistas que colaborativamente desenvolvam novas formas de compreensão da realidade e produzam novos saberes multi, inter e transdisciplinares. (FERNANDES, 2000, p. 140)
\end{abstract}

Vivencia-se uma crise educacional, sintoma de uma crise global, de civilizações que passam a questionar as lógicas predominantes na sociedade atual. Para Moraes (1996) as crises contemporâneas são manifestações de um conflito cultural mais profundo: trata-se de um momento crítico de mudança de visão de mundo. Esse imperativo impõe mudanças na relação homem $x$ conhecimento tendo em vista novas formas de conceber e de pensar a realidade. Essa crise não atinge só indivíduos, mas também governos, instituições, ou seja, é um choque com o paradigma científico dominante da forma de compreender e traduzir o mundo.

Nesse contexto, reformas educacionais vêm sendo implantadas no mundo todo visando 
adequar o sistema de ensino às mudanças na economia e na sociedade. Alarcão (2003) denomina a Era em que se vive como "sociedade da informação", "sociedade aprendente" (ASSMANN,1998, p. 17), era das relações, do conhecimento em rede. Tais mudanças, de caráter acentuadamente multicultural, demandam novos papéis da universidade, da formação do professor e do aluno.

O estudo de Thomas Kuhn (1922 -1996), físico, em “A Estrutura das Revoluções Científicas" (1970) fornece subsídios para o entendimento desse momento a partir do texto que trouxe à tona o uso do conceito de "paradigma", que, na filosofia, significa modelo ou exemplo. Os estudos desse autor foram predominantemente realizados com base na análise do progresso científico ocorrido na Física no contexto da História da Ciência. Kuhn divide o desenvolvimento científico em dois grandes componentes: ciência normal e revolução científica.

Isso remete ao que Sousa Santos (2006) identifica como um tempo de transição paradigmática entre o moderno (paradigma dominante) e o pós-moderno (paradigma emergente), em que onde de um lado, prevalecem as verdades incontestáveis e as simplificações e de outro, as dúvidas, a imprevisibilidade e a complexidade. Nesse âmbito, é que emergem as recentes reformas educacionais tendo em vista a adequação da educação às novas exigências impostas pela realidade produtiva mundial. Por conseguinte, a universidade, por ser uma das instituições sociais voltadas para a formação e qualificação profissional , está sendo questionada e convidada a se reestruturar em vista de responder aos novos desafios colocados. A necessidade de adequar a força de trabalho às necessidades do processo produtivo vem provocando um intenso movimento pela busca da qualidade inspirado basicamente pelas profundas mudanças na estruturação das empresas, em curso no universo econômico, no qual o conhecimento se torna cada vez mais, o principal fator de produção.

Nesse cenário de transformações, a concepção da escola, da universidade suas funções e relações com a sociedade, o conhecimento e a construção de identidades pessoais, sociais e culturais encontram-se em questionamento. Assim, faz-se necessário esclarecer o que se entende por educação, universidade e, em seguida, discutir o termo qualidade.

A educação é uma das condições de humanização, condição pela qual os indivíduos aprendem e se desenvolvem, essa exigência social e individual é atendida pela educação na medida em que é por meio dela que as características especificamente humanas são desenvolvidas. Conforme Talízina (1988, p.34):

0 homem não nasce com formas de pensar pré-estabelecidas, com conhecimentos prontos sobre o mundo nem descobre novamente as leis do pensamento lógico nem as leis da natureza que a sociedade conhece: assimila tudo isso mediante a experiência acumulada pelas gerações anteriores. Subentende-se que, só depois de assimilar a experiência social e a ela recorrendo, o homem pode multiplicar essa experiência.

Isso equivale dizer que, pela educação, o ser humano encontra os meios para assimilar a experiência da sociedade e multiplicá-la. Sem negar a importância dos aspectos anatômico-fisiológicos indispensáveis ao desenvolvimento do indivíduo, 0 modo social de vida do ser humano, com suas leis e métodos específicos, é que determina o desenvolvimento humano.

Por esses motivos é que a dupla função do ensino superior não pode ser dissociada. Se por um lado, ele é via de formação profissional, implicando a aprendizagem de um conjunto de conhecimentos, valores, domínios metodológicos e técnicos, é, também via estruturante de recursos afetivo-cognitivos imprescindíveis para que os estudantes possam conhecer com o devido rigor, cientificidade e criticidade, não apenas as dimensões técnicas do seu futuro exercício profissional, como também as condições históricas, culturais e sociais nas quais esse exercício ocorrerá. No caso dos egressos dos cursos de Contábeis, espera-se que atuem não apenas como técnicos, 
mas como gestores das organizações, de modo a desenvolverem métodos eficazes e a manusearem ferramentas que estruturem tomadas de decisões nas diferentes situações profissionais que possam enfrentar.

Uma entidade social como a universidade possui características que lhes são próprias e esse conjunto de caracteres próprios e exclusivos da instituição a identifica e a torna única. A universidade, neste sentido, é um todo que agrega uma diversidade de campos do saber, ou seja, uma unidade na diversidade, tendo como uma de suas principais características a indissociabilidade entre ensino, pesquisa e extensão e, nesse âmbito, a autonomia acadêmica, didática, administrativa e de gestão.

Entretanto, hoje em dia, essas definições esfacelam-se em meio à vulgarização e expropriação do conceito de universidade e do seu papel social, tendo em vista o caráter profissionalizante do ensino superior e a função da universidade como uma entidade administrativa, que se coloca a serviço do mercado de trabalho e à capacitação dos acadêmicos para novos postos de trabalho, em detrimento da formação para a cidadania ativa, para o que a autonomia, o senso crítico e o desenvolvimento intelectual são pontoschaves no processo de inserção social e profissional.

Esse fato suscita questões como a retomada da identidade da universidade e o desenvolvimento intelectual, crítico e reflexivo dos alunos coloca em pauta a questão da qualidade. A Qualidade da universidade refere-se tanto a atributos ou características de sua organização e funcionamento quanto ao grau de excelência, baseado numa escala de valores que pode ir de ruim, péssima, boa, excelente etc., embora haja grande diversidade de opiniões entre educadores, gestores, alunos etc., sobre critérios de qualidade das universidades, os profissionais de cada universidade e área do conhecimento envolvidos, precisam estabelecer um consenso mínimo sobre o padrão de qualidade que orientará seu trabalho educacional.

Educadores e pesquisadores, preocupados com a precariedade dos sistemas de ensino superior no Brasil (GADOTTI, 2006; DEMO, 1994; SOUSA SANTOS, 2006), discutem o conceito de qualidade do ensino universitário. Todos concordam que a universidade que se tem aí precisa elevar a sua qualidade, porém, entendem que há divergência quanto aos indicadores de qualidade, o que implica uma compreensão do papel da educação no processo de desenvolvimento do país.

Pois, se para alguns o papel da educação é de formar cidadãos conscientes e participativos capazes de ajudar a transformar as estruturas da sociedade, para outros, a educação é concebida como estratégia de desenvolvimento econômico. É pois no âmbito dessa segunda concepção de educação que se coloca o conceito Liberal de qualidade de ensino. Nessa perspectiva, os indicadores de qualidade estão submetidos a critérios de competitividade, produtividade, controle etc. Por isso é preciso "qualificar" a qualidade que se deseja pois se os objetivos, os valores, os compromissos são diferentes, então, os parâmetros, os critérios para se definir a qualidade também o serão. Se, por um lado, tem se falado em qualidade da educação, exigindo da universidade o desenvolvimento de novas habilidades em seus alunos tais como:

a) Capacidade de comunicação: saber buscar as informações, compreender com facilidade as mensagens recebidas e habilidade para expressar-se;

b) Habilidade de trabalho em grupo e Espírito cooperativo: habilidade para interagir com o grupo de trabalho, desejo de cooperar com a organização;

c) Raciocínio lógico: fundamental para a interação com as máquinas (inteligentes) e com as outras pessoas;

d) Criatividade: capacidade de propor ideias e soluções para os problemas colocados pela produção;

e) Visão de totalidade: habilidade de perceber as diversas partes/ 
momentos envolvidos num processo produtivo e a ligação entre eles;

f) Capacidade de abstração: capacidade de compreender os fenômenos e extrair suas características, chegando a generalizações.

Por outro, esse discurso, aparentemente democrático, é conservador e ideológico, pois ele tem como base a lógica do mercado. Em uma concepção Liberal, os critérios de qualidade do ensino são idênticos aos formulados pelas empresas: adaptabilidade e ajuste do mercado, competitividade, rentabilidade etc. Para Catani et al., (2001, p. 78), a ideia da adaptação e flexibilização é mais ampla e ideológica do se possa imaginar que:

\begin{abstract}
Virou palavra de ordem no tocante ao processo de globalização, ou melhor, de mundialização, especialmente para as chamadas economias emergentes. A idéia da adaptação é apresentada como processo benéfico e necessário. Trata-se, todavia, de questão que comporta uma forte dimensão ideológica, já que se adaptar tem significado liberalizar e desregulamentar a economia, conformar-se às estratégias das multinacionais e às imposições dos mercados financeiros. No tocante a reformulação curricular, isso poderá significar um processo de aligeiramento da formação visando à expansão e massificação da educação superior no país.
\end{abstract}

Nesse âmbito, a educação é encarda como instrumento da sociedade para garantir e manter a sua estrutura, normas e valores. Os indivíduos devem ser formados para se adaptarem às normas vigentes e ao mercado de trabalho. Nesse sentido, a transformação social e a cidadania não são determinantes. Diferentes autores (LIBÂNEO, 2001; SAVIANI, 2003, 2007; DIAS SOBRINHO, 2005, 2009; CATANI et al., 2001) reconhecem essa abordagem tradicional da educação e asseveram que se trata de uma ideologia da educação de orientação vocacional ou neoclássica, na qual a escola deve manter, reproduzir e legitimar a estrutura econômica e política da sociedade.

Para Kuenzer ( 2001), as mudanças ocorrentes no mundo do trabalho, resultantes da inserção da economia brasileira no processo de globalização, principalmente a partir da década de 90, apresentaram impactos expressivos para a educação. Concordando com essa ideia, Machado (2003) observa que a lógica do currículo por competências é implantada pelas reformas educacionais, por meio de políticas que buscam promover ajustes no sistema educacional visando a atender às transformações na esfera do trabalho, decorrentes dos processos de desintegração dos padrões de organização baseados no taylorismo-fordismo, da globalização, da desregulamentação dos direitos trabalhistas, da flexibilização das relações de trabalho e do desemprego estrutural.

Essas discussões evidenciam que as configurações do vigente regime de acumulação de capital, baseadas em novas tecnologias de produção, exigiram o redesenho de processos de aprendizagem sociocultural, uma vez que se tornaram necessários subsídios aos novos saberes e exigências organizacionais. Conforme Trujillo (2000), o conhecimento requerido pelas novas formas de acumulação de capital não se restringe ao desempenho de um trabalho eficiente, mas, sim, enfatiza os aspectos cognitivos, de conduta e psicofisiológicos dos indivíduos.

Compreender a educação do ponto de vista dinâmico e transformador e os indivíduos como capazes de transformar a realidade e se transformarem implica visão igualmente crítica. Nessa perspectiva, procura-se formar sujeitos preparados para a responsabilidade social. Acredita-se que a sociedade desenvolve-se por meio de individuos autônomos, críticos e reflexivos. Isso implica entender que, preparar para cidadania, exige o desenvolvimento de habilidades, hábitos, valores e convicções que de um lado, incluem:

a) a qualidade formal, que significa a habilidade de manejar meios, 
instrumentos, formas, técnicas procedimentos diante dos desafios do desenvolvimento. $\mathrm{E}$, de outro lado (...),

b) a qualidade política quer dizer a competência do sujeito em termos de se fazer e de fazer história, diante dos fins históricos da sociedade humana. É condição básica da participação. Dirige-se a fins, valores e conteúdo. A qualidade dos meios esta em função da ética dos fins. A qualidade dos fins depende da competência dos meios (DEMO, 1994, p. 14-15).

Desse ponto de vista, "questões como produtividade, eficácia e eficiência precisam se articular à efetivação da noção de educação superior como um direito social inalienável para todos" (DOURADO, et al. 2001, p.15). Por isso, o desafio de um projeto de qualidade da educação voltado para as duas competências apontadas por DEMO (1994), exige uma tomada de posição sobre com qual projeto de qualidade se está comprometido nesse novo século.

A qualidade da educação que se busca não acontecerá somente por meio da democratização do acesso e permanência dos alunos no sistema de ensino, (educação quantitativa que, via massificação do ensino, adota o tecnicismo e o racionalismo conservadorista) mas, que alunos que ali permanecem por longo período, não somente tenham acesso as informações, mas, essencialmente, acessem ao conhecimento, ou seja, à aprendizagens significativas. Isso significa dizer que a qualidade da educação não pode ser vista pela lógica da racionalidade técnica, mas pela lógica da cidadania ativa, do exercício do direito de participação, da construção da autonomia cognitiva que se dá por meio de metodologias que fomentam conflitos cognitivos como essenciais às atividades de aprendizagem e, assim, à construção do conhecimento no contexto universitário.

Nesse contexto, o centro de referência dos critérios e estratégias de qualidade é o que os alunos aprendem, como aprendem e, em que grau, são capazes de pensar e atuar com o que aprendem.

\section{EIXOS DA QUALIDADE: A REFORMA CURRICULAR E OS PROCESSOS DE ENSINO E APRENDIZAGEM}

O eixo da qualidade do ensino gira em torno da qualidade da aprendizagem dos alunos. Os currículos devem atender as necessidades dos alunos em consonância com as exigências sociais e educacionais contemporâneas. Isso significa que devem prestar atenção nos conteúdos que estão sendo ensinados, no modo como estão sendo ensinados, na efetividade desses conteúdos para a vida cultural e prática. Daí o investimento no aperfeiçoamento do currículo e das práticas metodológicas no interior das IES, mas especificamente de cada curso.

As discussões curriculares são permeadas por questões sobre a proposta de educação que se deseja implementar, a construção do projeto político pedagógico e nesse ẩmbito, é definido o que ensinar (conjunto de disciplinas) e o aluno que se quer formar, ou seja, o perfil do egresso do curso. Nesse sentido, o currículo atua como filtro sobre o que o aluno deve saber para poder desenvolver determinada função social (define o saber e o fazer do aluno).

Tendo em vista essas ideias, o currículo constitui, então, o elemento nuclear do projeto pedagógico, é ele que viabiliza o processo de ensino e de e aprendizagem. Defende-se, neste artigo, o conceito de currículo como um desdobramento necessário 
do projeto pedagógico, ele transforma intenções e orientações previstas no projeto, em objetivos, conteúdos etc., ou seja, em plano de ação. O currículo torna-se a orientação prática para a ação, é um nível de planejamento que fica entre o PPP e a ação prática. Enquanto a projeção do PPP, o currículo define: "o que ensinar"? 0 para que ensinar? O como ensinar? E as formas de avaliação, em estreita colaboração com a didática.

Ou seja, os currículos definem quem formar e para que formar? Daí o investimento no aperfeicoamento do currículo e das práticas metodológicas no interior das IES. Isso significa dizer: é preciso ficar atento aos conteúdos que estão sendo ensinados, ao modo como estão sendo ensinados, à efetividade desses conteúdos para a vida cultural e prática.

Existem distintas concepções e posições sobre os currículos, que as serão discutidas a seguir.

\subsection{A CONCEPÇÃO CENTRALIZADA DE GESTÃO E DESENVOLVIMENTO CURRICULAR}

Nessa visão, o currículo deve ser planejado, administrado e controlado por órgãos superiores do sistema nacional (Ministério da Educação, Secretaria da Educação etc.). Nele são definidas as metas a alcançar, metodologias e técnicas a serem seguidas, possui um sistemas avaliação controlador. A ênfase está posta nos interesses mais amplos do sistema político global e não nos interesses regionais e locais. Essa concepção de currículo ainda é dominante no contexto brasileiro, para o qual a qualidade da universidade possui critérios idênticos aos formulados pelas empresas, pois a função da educação superior é a formação de profissionais para o mercado.

Para Leite e Morosini (1992), essa perspectiva de currículo foi adotada no sistema superior brasileiro desde seu início (até hoje). A universidade brasileira é tardia, ao contrário de outros países, o ensino superior brasileiro iniciou-se em 1808, no período colonial, com a criação de escolas isoladas, em consequência do pacto colonial entre as nações europeias de toda a América. Até então, os brasileiros eram enviados para a Europa para estudar, a formação de bacharéis e doutores aconteceu em Coimbra.

Nessa mesma linha de pensamento, MASETTO (2003) diz que a universidade brasileira, desde seu início, se estruturou segundo o modelo franco-napoleônico, o qual se caracteriza por uma organização não universitária, mas profissionalizante, centrado em cursos e faculdades, visando à formação de burocratas para o desempenho das funções do estado.

A adoção desse modelo teve por finalidade proceder à unificação ideológica e o conservadorismo da época. Para o autor o modelo brasileiro, adaptado do francês, tinha como características: formação de profissionais para exercerem uma determinada profissão (especialização); currículos seriados e programas fechados, que constavam, unicamente, das disciplinas que interessavam, imediata e diretamente, ao exercício da profissão desejada pelo aluno; corpo docente composto por professores formados por universidades europeias e processo de ensino e aprendizagem no qual um professor detentor de conhecimentos e experiências profissionais, transmitia-os para um aluno que não sabia e não conhecia, sendo a avaliação desse processo responsável pela outorga ou não do diploma ou certificado de competểncia que permitiria àquele aluno exercer determinada profissão.

O modelo mundial de currículo baseia-se no paradigma científico positivista, que encara o conhecimento como estático, definitivo, objetivo, afastado de determinantes históricos e condicionantes mais amplos - dos processos sociais. Nesta perspectiva, currículo é tido como programa, instrumento de natureza técnica, traduzido na organização da prática pedagógica através do elenco de conteúdos ordenados sequencialmente por meio de matérias e /ou disciplinas isoladas (COIMBRA, 
2006), conforme se pode visualizar no quadro a seguir:

\begin{tabular}{|c|}
\hline Perspectiva Cartesiana/fragmentada \\
\hline O Currículo é centrado na transmissão de conteúdos \\
\hline O professor é o único informante com o papel de dar respostas certas e cobrar sua memorização. \\
\hline $\begin{array}{l}\text { O aluno visto e tratado objeto da educação, é dependente e recebe passivamente o conteúdo } \\
\text { ministrado pelo professor. }\end{array}$ \\
\hline $\begin{array}{l}0 \text { Conhecimento é visto como um acúmulo de fatos isolados e distanciados da realidade dos } \\
\text { alunos. }\end{array}$ \\
\hline $\begin{array}{l}\text { O conteúdo é visto e tratado de forma isolada, são as partes de permitem o entendimento do todo. } \\
\text { Há uma sequência rígida dos conteúdos das disciplinas, com pouca flexibilidade no processo de } \\
\text { aprendizagem. }\end{array}$ \\
\hline Método baseia-se fundamentalmente em exercícios e atividades do livro didático. \\
\hline O tempo e o espaço da aprendizagem são organizados de forma rígida. \\
\hline Propõe receitas e modelos prontos reforça a repetição e o treino e aguarda respostas únicas. \\
\hline Aprendizagem é o acúmulo, retenção da informação. \\
\hline O ensino é a transmissão de conhecimentos acumulados pela humanidade. \\
\hline
\end{tabular}

Quadro 1 - Concepção tradicional de Currículo

Para Cunha (1998) a forte presença do paradigma da ciência moderna positivista na sociedade ocidental acabou por cristalizar a forma tradicional de curriculo, pois esta é vista como uma única possibilidade de organização. Este modelo resume-se numa lógica presente no nosso cotidiano acadêmico: dos fundamentos da ciência para sua aplicação; da teoria para prática; do básico para o profissionalizante. 0 conceito de aprendizagem, sustentado por esta concepção, parte do pressuposto de que primeiro o sujeito deve "adquirir" conhecimentos para depois poder aplicálos na prática e em situações específicas. Entende, também, que a melhor forma de aprender é pela audição e registro das verdades científicas reconhecidas que, para serem adquiridas, precisam de exercícios de experimentação e memorização. A qualidade de um curso é medida pela extensão da carga horária das disciplinas e, portanto, quanto mais horas/aula o aluno cumpre, melhor é sua formação. A prática é entendida como a comprovação da teoria, sendo que seu sucesso depende do grau de aproximação com o conhecimento já construído.

Estas ideias são reforçadas por Kincheloe (1997, p.13), quando ressalta que "a racionalidade foi deificada pelos currículos escolares [...] o mundo natural é racional (egocêntrico) e existe somente um sentido único para ele. Todo o fenômeno natural pode ser pintado dentro de uma moldura desta racionalidade monolítica, não importando se estamos estudando a pólvora, engenhos, sonhos ou mesmo aprendendo".

As reformas curriculares da atualidade (LDB/1996) buscam a superação deste modelo. A Lei de Diretrizes e Bases da educação brasileira 5692/68 solicitava, apenas, o cumprimento das orientações emanadas do poder central. A falta de participação dos professores na elaboração das propostas educacionais e a falta de clareza na compreensão da ideia de "projeto", tem favorecido a implantação burocrática e fragmentada do currículo.

Pode-se dizer, então, que os modelos de educação decorrem do modelo 
de ciência em voga na sociedade, o qual influência diretamente, as teorias de aprendizagem das quais derivam modelos e práticas curriculares correspondentes (disciplinar ou interdisciplinar). Em termos de educação superior, de acordo com Moraes, 1996, p. 58):

O modelo ainda é o de dividir o conhecimento em assuntos, especialidades, subespecialidades, centrada no professor e na transmissão do conteúdo que, em nome da transmissão do conhecimento, continua vendo o indivíduo como uma tabula rasa, produzindo seres subservientes, obedientes, castrados em sua capacidade criativa, destituídos de outras formas de expressão e solidariedade. E uma educação "domesticadora", "bancária", segundo Paulo Freire, que "deposita" no aluno informações, dados e fatos, onde o professor é quem detém o saber, a autoridade, que dirige o processo e um modelo a ser seguido.

Essa ideário indica os pressupostos epistemológicos nos quais a educação superior se assenta. Nesse sentido, Cunha (1998, p. 1) afirma que:

\begin{abstract}
A forte presença do paradigma da ciência moderna na sociedade ocidental o positivismo a que acabou por cristalizar a forma tradicional de currículo, vendo-a como uma única possibilidade de organização. Esta, resumese na lógica presente no nosso cotidiano acadêmico: dos fundamentos da ciência para sua aplicação; da teoria para prática; do básico para o profissionalizante.
\end{abstract}

Esta lógica de organização curricular separa pensamento e ação, é sustentada pela teoria de aprendizagem ambientalista/empirista que parte do pressuposto de que primeiro o sujeito deve "adquirir" conhecimentos para depois poder aplicá-los na prática e em situações específicas.

\title{
3.1.1 UMA EVIDENCIAÇÃO DA PRESENÇA DO PARADIGMA MODERNO NA EDUCAÇÃO CONTÁBIL
}

O cenário educacional, na área Contábil, não se diferencia do das demais áreas que, ainda, permanecem voltadas para a profissionalização, sem dar maior importância ao que Demo (1994) chama de qualidade formal (habilidade de manejar meios, instrumentos, formas, técnicas, procedimentos, diante dos desafios do desenvolvimento) e de qualidade política (competência em termos de se fazer e de fazer história, ante os fins históricos da sociedade humana) e que a qualidade dos meios devem estar em função da ética dos fins: a qualidade dos fins depende da competência dos meios.

No que tange ao cenário educacional na área Contábil, estudiosos, pesquisadores, educadores e profissionais avaliam como delicado e preocupante e apontam como principais causas dificultadoras e problemáticas a falta de adequação curricular e, atrelada a ela, a falta de um programa definido para a prática contábil, bem como a falta de preparo do corpo docente, deficiência na metodologia de ensino da Contabilidade introdutória e a proliferação das instituições de ensino e órgãos de classe.

Para Nossa (1999), a melhoria na qualidade de ensino, assenta-se nas mudancas curriculares e estruturais das IES, na seriedade, dedicação e compromisso assumido pelos profissionais com vistas à formação profissional de qualidade e não apenas disponibilidade de informações sobre alģuns conteúdos. Para ele, torna-se necessária 
a implementação do Currículo que forma o Contador Global, em que o conteúdo é trabalhado de forma interdisciplinar.

Nessa mesma linha, (LIMA, 1996, p. 55 ) também critica o modelo de educação que se tem na contabilidade quando ressalta que:

A obsessão pela eficácia e pela eficiência, definidas através do recurso a metáforas produtivistas e do discurso onipresente da qualidade, da avaliação, dos resultados, do rigor etc., vem assim definindo a educação que conta - aquela que é orientada segundo objetivos precisos e que dessa forma se torna contável através da ação de instâncias de contadoria e dos respectivos agentes e processos contadores. (...) $\mathrm{Na}$ educação contábil, a definição objetiva e consensual dos objetivos (bem conhecida das pedagogias científicas e racionalizadoras) e o recurso a todo o tipo de avaliações (de pessoal, dos alunos, das instituições, dos cursos etc.), foram transformados em preciosos meios de controle político e administrativo, científico e pedagógico.

Pode-se dizer que, nesse modelo de ensino, a melhor forma de aprender é pela audição e registro das verdades científicas reconhecidas que, para serem adquiridas, precisam de exercícios de experimentação e memorização. Nessa lógica que move a educação e o modelo de currículo, tem-se que a qualidade de um curso é medida pela extensão da carga horária das disciplinas e, portanto, quanto mais horas/aula o aluno cumpre, melhor é sua formação. A prática é entendida como comprovação da teoria, sendo que seu sucesso depende do grau de aproximação com o conhecimento já construído (CUNHA, 1998).

Em relação ao perfil do egresso do curso de Contábeis, Dagostim (2000) destaca que o contador atual, diferentemente daquele da década de 1945, que recebia os dados monetários, processava, extraía informações econômicas, financeiras e patrimoniais, deve ser um profissional preocupado com os resultados da empresa e com o sucesso do empreendimento. Para tanto, deve ser participativo, ligado não somente ao desempenho econômico-financeiro, mas envolvido com o social, o ambiental e a administração da empresa, tomando parte nas decisões.

Esta postura técnica e limitada dos egressos também é criticada por Marion (1996) quando diz que os alunos de Contábeis quanto à aprendizagem da Contabilidade Aplicada e em vista da excessiva concentração de disciplinas de natureza técnica, a visão do profissional fica restrita à escrituração Contábil.

Os Cursos de Contabilidade precisam encontrar novas formas de ensinar e aprender, no intuito de tornar o ensino mais eficiente, e, contudo, agradável, pois aprender precisa ter sabor, gosto, prazer. 0 paradigma dominante hoje é de ensino utilitarista, reducionista, comportamental no qual onde o aluno responde ao estímulo e, ao final, faz uma avaliação para verificar a quantidade de conteúdo retido, para ser aprovado, mesmo que não tenha aprendido.

O papel da Matriz Curricular para os cursos de Ciências Contábeis é discutido por Riccio e Sakata, (2004) que apontam os limites das pesquisas que se voltam para questões de ensino e aprendizagem, que se focam em questões periféricas como sexo, raça, habilidades técnicas etc. Destacam os autores que uma discussão que se torna importante nos dias de hoje é a internacionalização e a globalização de programas acadêmicos que podem envolver conhecimento de línguas estrangeiras, 
cultura geral, entre outros conhecimentos.

De acordo com estas ideias, Araujo et al., (2008, p. 99) dizem que:

A Teoria da Contabilidade está sujeita à influência dos mais diversos elementos sociais, políticos e científicos e deve 'beber' em outras áreas de conhecimento na perspectiva de fundamentar teoricamente seus construtos, utilizando-se da transdisciplinaridade inerente às ciências sociais aplicadas.

Esses resultados são reforçados pelo estudo de Passos (2004) que investigou a percepção de coordenadores dos cursos de Ciências Contábeis sobre pesquisa, planejamento pedagógico e matriz curricular. Os resultados revelaram a existência de um ensino técnico, centrado no mercado de trabalho e em matérias técnicas da área contábil, com baixo nível de relacionamento entre disciplinas.

Os cursos de Contabilidade podem, por meio de um novo olhar curricular, desenvolver ações de interdisciplinaridade que, no dizer de Fazenda (2002, p.11), têm-se "uma nova atitude diante do conhecimento, de abertura à compreensão dos aspectos envolvidos no ato de aprender colocando-os em questão". Um Currículo interdisciplinar possibilita aprendizagens colaborativas, simulações, vivências, estudo de caso e tem a investigação científica como meta prioritária para a construção do conhecimento e da autonomia do aluno.

Entretanto, pesquisas recentes apontam um contexto guiado pelo paradigma científico dominante e um contexto bastante precário. Gomes et al. (2009) analisaram o Projeto Político Pedagógico dos Cursos de Ciências Contábeis das Universidades Públicas do Estado da Bahia e, além de outros problemas, apontam limitações em relação à matriz curricular desses cursos que evidenciam desarticulação entre o mundo da academia e a sociedade em que o conhecimento constante do currículo parece não refletir a realidade e as necessidades dos formandos e como consequência a dicotomia entre a teoria e a prática. Os autores sugerem, como superação dessa problemática, acões das IES em prol dessa integração pela construção coletiva do PPP e do currículo interdisciplinar como instrumento de sua concretização.

Padoan e Clemente (2006) realizaram estudo semelhante com os docentes do curso de Contábeis e postulam que "a Contabilidade é sustentada por três teorias: mensuração, informação e decisão. [...]" Ao estudarem as disciplinas em vista da integração e articulação dos conhecimentos contábeis, apontaram para a importância da Interdisciplinaridade na formação do Contador. 0 estudo evidenciou os seguintes pontos: prevalência do tecnicismo no ensino de Contabilidade e do conteudismo; quantidade de disciplinas em detrimento da qualidade do ensino desses conteúdos e, como consequência, visão pouco integradora das disciplinas. Os autores apontam para a necessidade de revisão da proposta pedagógica e para a superação da disciplinaridade, em prol de uma formação dos futuros profissionais, que lhes dê condições de desempenhar com competência sua profissão.

Esses resultados são reforçados pelo estudo de Passos (2004) que investigou a percepção de coordenadores dos cursos de Ciências Contábeis sobre pesquisa, planejamento pedagógico e matriz curricular. Os resultados revelaram a existência de um ensino técnico, centrado no mercado de trabalho e em matérias técnicas da área contábil, com baixo nível de relacionamento entre disciplinas.

Esses dados haviam sido reforçados no estudo de Paiva (1999, p. 93) quando informou que "a interdisciplinaridade dentro do próprio curso de Ciências Contábeis é praticamente inexistente". A razão é a de que as disciplinas são ministradas de forma isolada. Ele conclui que o aluno não consegue formar uma compreensão global e indivisível da Contabilidade como Ciência, por receber uma visão fragmentada 
de várias Contabilidades: gerencial, comercial, industrial, pública, bancária, sem integração entre as disciplinas.

Essas discussões acentuam o entendimento de que a concepção curricular analisada não coaduna com os ideais da contemporaneidade e também não se aproxima do conceito de qualidade que se defende para a universidade, necessitando, assim de projetos de educação e de modelos curriculares que resgatem a identidade e a autonomia da universidade brasileira no contexto da multicuturalidade/ diversidade.

\subsection{A CONCEPÇÃO DESCENTRALIZADA E DEMOCRÁTICA DE GESTÃO E DESENVOLVIMENTO CURRICULAR}

A concepção descentralizada e democrática de currículo confere importância, tanto aos órgãos de coordenação central - visando, uma certa unidade do sistema escolar em função de objetivos democráticos da educação nacional - com também à coordenação e interesses locais. Esta voltada para a flexibilidade, a liberdade e o caráter participativo. Esse modelo busca, portanto, incentivar os professores de cada IES a melhorar o processo educativo, a refletir sobre as práticas curriculares e metodológicas, a fim de oferecer serviços de melhor qualidade aos seus alunos. Sob esse enfoque, torna-se possível o agrupamento de disciplinas, cursos e várias IES em torno de projetos comuns de aperfeiçoamento curricular, capacitação de professores, de pesquisas sobre a prática de ensino e da melhoria da qualidade da educação superior.

As reformas curriculares da atualidade caminham nessa direção, entretanto, os diferentes modelos de currículos encaminham políticas igualmente diferenciadas. Em seus estudos, Dias Sobrinho e Chauí discutem e defendem o conceito de universidade como instituição social em contraponto com a universidade operacional, que podem ser sintetizadas no quadro abaixo:

\begin{tabular}{|c|c|}
\hline $\begin{array}{c}\text { Universidade voltada para o Mercado } \\
\text { Função econômica } \\
\text { Avaliação=Controle }\end{array}$ & $\begin{array}{c}\text { Universidade voltada para projetos Sociais } \\
\text { Função social } \\
\text { Avaliação processual }\end{array}$ \\
\hline $\begin{array}{c}\text { Eficiência, lucro, produtividade, } \\
\text { competitividade, operacionalidade, } \\
\text { racionalidade instrumental, ética subjetivista, } \\
\text { sucesso individual }\end{array}$ & $\begin{array}{c}\text { Relevância social, equidade, pertinência, } \\
\text { democracia, cidadania, solidariedade, ética } \\
\text { social, autonomia, desenvolvimento social }\end{array}$ \\
\hline $\begin{array}{c}\text { Ênfase em resultados e produtos específicos, } \\
\text { segundo a lógica competitiva }\end{array}$ & $\begin{array}{c}\text { Ênfase em processos globais, segundo a } \\
\text { lógica dos interesses sociais }\end{array}$ \\
\hline $\begin{array}{c}\text { Controlar a qualidade como quantidade de } \\
\text { produtos e aumentar a competitividade, } \\
\text { segundo a lógica do mercado e do sucesso } \\
\text { individual. Informar o mercado (clientes) e a } \\
\text { administração central (para fins de regulação e } \\
\text { fiscalização). }\end{array}$ & $\begin{array}{c}\text { Melhorar/construir a educação } \\
\text { cooperativamente, segundo a lógica da } \\
\text { qualidade social e do sentido público. }\end{array}$ \\
$\begin{array}{c}\text { Informação pública com finalidade de formar } \\
\text { melhor, consolidar a instituição, melhorar a } \\
\text { função social. }\end{array}$ \\
\hline
\end{tabular}

Quadro 2 - Função social da Universidade

Fonte: Elaborado pelos autores com base nos estudos de Dias Sobrinho (2005; 2008a-b; 2009) e Chauí (2001)

Um dos pesquisadores preocupados com a qualidade formal e política da educação como Demo (1994) questiona a qualidade do conhecimento produzido na 
universidade e dos processos educativos pelos quais é responsável, quais sejam, a disseminação do conhecimento científico e a formação de profissionais e cidadãos nas diferentes áreas, por isso não pode se deixar levar pela lógica de mercado (DIAS SOBRINHO, 2005). Essas discussões evidenciam a necessidade emergente de resgatar a identidade e a finalidade da educação superior no contexto brasileiro.

A função da universidade, nesse milênio, é a de zelar pela qualidade do trabalho acadêmico que realiza e pela competência dos profissionais que forma. Desse modo, "o sentido essencial da responsabilidade social da educação de nível superior consiste em produzir e socializar conhecimentos que tenham não só mérito científico, mas também valor social e formativo" (DIAS SOBRINHO, 2005, p. 172). Essa concepção de currículo vem sendo defendida no ensino de graduação brasileiro quando da institucionalização das Diretrizes Curriculares Nacionais dos cursos de graduação a partir da nova Lei de Diretrizes e Bases da Educação Nacional (Lei 9.394/96), conforme se pode concluir das seguintes considerações inseridas no parecer CNE/CES n 583/2001, Plano Nacional de Educação, Lei 10.172 de janeiro de 2001, que define os objetivos e metas:

(...) 11. Estabelecer, em nível nacional, diretrizes curriculares que assegurem a necessária flexibilidade e diversidade nos programas oferecidos pelas diferentes instituições de ensino superior, de forma a melhor atender às necessidades diferenciais de suas clientelas e às peculiaridades das regiões nas quais se inserem (...)

Por sua vez o Parecer CNE/CES 776/97 estabeleceu orientação geral para as diretrizes curriculares dos cursos de graduação e entre outras considerações assinala:

Além do mais, os currículos dos cursos superiores, formulados na vigência da legislação revogada pela Lei 9.394, de dezembro de 1996, em geral caracterizam-se por excessiva rigidez que advém, em grande parte, da fixação detalhada de mínimos curriculares e resultam na progressiva diminuição da margem de liberdade que foi concedida às instituições para organizarem suas atividades de ensino e destaca: Visando assegurar a flexibilidade e a qualidade da formação oferecida aos estudantes, as diretrizes curriculares devem observar os seguintes princípios [...].

Em síntese, o currículo e os processos de ensino e aprendizagem correspondem a objetivos da formação profissional, ou seja, realizam atividades-fim na educação, tais como: a aquisição do conhecimento e da cultura da universidade o desenvolvimento da personalidade; a formação para a cidadania e, como consequência, a inserção no mercado de trabalho.

A adoção dessa visão requer um entendimento sobre a finalidade do ensino superior no contexto social global que determina e é determinado pela ação dos sujeitos que aí atuam, uma vez que a finalidade das instituições de educação é essencialmente de formação humana e, por sua excelência, é um "sistema de relações, com características interativas, que as diferenciam das empresas convencionais" (LIBÂNEO, 2001, p. 77). A universidade, como instituição social, lida com a formação humana e o "exercício permanente da crítica, que se sustenta na pesquisa, no ensino e na extensão” (PIMENTA e ANASTASIOU, 2002, p. 162). Nessa condição, a universidade:

Caracteriza-se como ação e prática social, pautando-se pela idéia de um conhecimento guiado por suas próprias necessidades e por sua própria lógica, tanto no que se refere à descoberta e invenção quanto à disseminação e produção do conhecimento. Desde suas origens, a universidade buscou efetivar os princípios de formação, criação, reflexão e crítica, tendo sua legitimidade derivada da autonomia do saber ante a religião e o Estado (Idem, p. 168). 
Em decorrência dessas características e finalidades da IES, alguns princípios organizacionais e de funcionamento se impõem:

A convicção de que os espaços institucionais, democraticamente constituídos, por expressarem e contemplarem a diversidade e a pluralidade de pensamento, são espaços legítimos para efetivar essa finalidade; a convicção de que o processo educativo de qualidade resulta da participação dos sujeitos nos processos decisórios, o que se traduz no fortalecimento de práticas colegiadas e na condução dos projetos e das ações educativas na universidade (Ibidem, p. 163)

Essas ideias evidenciam que em uma IES, orientada por princípios democráticos e participativos, o processo de tomada de decisão dá-se de forma coletiva, descentralizada e coletiva. Essa forma de agir acentua a importância de se perseguirem objetivos comuns assumidos por todos. Em termos de proposta pedagógica do curso de graduação significa clareza sobre qual o papel social da educação superior? Sobre o perfil de egresso do curso? Ou seja, que homem se quer formar? Para viver em que sociedade?

Um dos principais critérios de aferição dos resultados obtidos em relação a esses questionamentos que conduzem a políticas e objetivos educacionais é o grau em que se obtém a qualidade cognitiva e operativa das aprendizagens escolares. As atividades-meio são as condições de realização desses objetivos, incluindo, entre essas condições: o planejamento pedagógico e curricular, a organização e gestão da universidade; a cultura organizacional, a tecnologia; o desenvolvimento profissional dos professores.

O projeto pedagógico-curricular é o instrumento de articulação entre meio e fins, ele faz o ordenamento de todas as atividades pedagógicas, curriculares e organizativas da IES, tendo em vista os objetivos educacionais. A garantia da qualidade do ensino é, portanto, a crença na possibilidade do aluno, além do acesso e permanência na universidade, acesso ao conhecimento, que por nela deve ser produzido por meio de: um trabalho integrado e articulado, com a participação coletiva na elaboração e desenvolvimento do projeto pedagógico e do currículo; a atuação competente dos professores nos conteúdos e na metodologia de ensino, implicando atualidade e relevância social desses conteúdos; alcance de resultados que evidenciem a eficácia do trabalho da IES e dos professores.

A reforma curricular, a partir da LDB (1996), é uma tentativa de formar profissionais qualificados, ao propor a autonomia das IES, estabelece diretrizes para o projeto pedagógico e busca a flexibilização curricular. O Parecer $\mathrm{N}^{\circ} \mathrm{CES} / \mathrm{CNE} 0146$ (2002) estabelece as Diretrizes Curriculares Nacionais para os cursos de graduação que devem: “a) se constituir em orientações para a elaboração dos currículos; $b$ ) ser respeitadas por todas as IE e, c) assegurar a flexibilidade e a qualidade da formação oferecida aos estudantes".

Em relação a área Contábil, indica que o curso deverá contemplar um perfil profissional que revele: "a responsabilidade social de seus egressos e sua atuação técnica e instrumental, articulada com outros ramos do saber e, portanto, com outros profissionais, evidenciando o domínio de habilidades e competências inter $e$ multidisciplinares" (CES/CNE, 2002, p. 14).

Para tanto as IES deverão estabelecer a organização curricular por meio de Projeto Pedagógico, com descrição dos seguintes eixos interligados de formação: I - Conteúdos de Formação Básica; II - Conteúdos de Formação Profissional; III Conteúdos de Formação Teórico-Prática (CES/CNE, 2002, p. 15).

Por sua vez, a Resolução 10 de 16 de dezembro de 2004 elenca as competências 
e habilidades necessárias para o curso de Ciências Contábeis no seu artigo $4^{\circ} \mathrm{em}$ que diz que o curso de graduação em Ciências Contábeis deve possibilitar formação profissional que revele, pelo menos, as seguintes competências e habilidades:

I - utilizar adequadamente a terminologia e a linguagem das Ciências Contábeis e Atuariais;

II - demonstrar visão sistêmica e interdisciplinar da atividade contábil;

III - elaborar pareceres e relatórios que contribuam para o desempenho eficiente e eficaz de seus usuários, quaisquer que sejam os modelos organizacionais;

IV - aplicar adequadamente a legislação inerente às funções contábeis;

$V$ - desenvolver, com motivação e através de permanente articulação, a liderança entre equipes multidisciplinares para a captação de insumos necessários aos controles técnicos, à geração e disseminação de informações contábeis, com reconhecido nível de precisão;

$\mathrm{VI}$ - exercer suas responsabilidades com o expressivo domínio das funções contábeis, incluindo noções de atividades atuariais e de quantificações de informações financeiras, patrimoniais e governamentais, que viabilizem aos agentes econômicos e aos administradores de qualquer segmento produtivo ou institucional o pleno cumprimento de seus encargos quanto ao gerenciamento, aos controles e à prestação de contas de sua gestão perante à sociedade, gerando também informações para a tomada de decisão, organização de atitudes e construção de valores orientados para a cidadania;

VII - desenvolver, analisar e implantar sistemas de informação contábil e de controle gerencial, revelando capacidade crítico analítica para avaliar as implicações organizacionais com a tecnologia da informação;

VIII - exercer com ética e proficiência as atribuições e prerrogativas que lhe são prescritas através da legislação específica, revelando domínios adequados aos diferentes modelos organizacionais.

Essas competências e habilidades poderão ser desenvolvidas por meio de um projeto de educação comum, o qual exigirá que os educadores de cada instituição educacional elejam um conjunto de intenções educativas e de diretrizes pedagógicas e que se articule para orientar a organização e o desenvolvimento da sua prática educativa. Referenciais mais amplos - de natureza político-filosófica, epistemológica e didático-pedagógica, definidos conjuntamente, oferecerão as bases para a análise da realidade atual da universidade e o planejamento da intervenção sobre ela.

Pode-se, então, dizer que a proposta pedagógica (PPP) para o curso de Ciências Contábeis, capaz de atender as necessidades dos alunos e a melhoria da qualidade do ensino, até aqui defendida, será posta em prática por meio de um currículo interdisciplinar. Nessa proposta não mais fragmentada, conforme já discutido neste texto, será posta em pratica todo Projeto Pedagógico intimamente articulado ao compromisso sociopolítico com os interesses reais e coletivos. É político no sentido de compromisso com a formação do cidadão para um tipo de sociedade (VEIGA, 2004).

$\mathrm{Na}$ dimensão didático-pedagógica reside a possibilidade da efetivação da intencionalidade da universidade que é a formação do cidadão participativo, responsável, compromissado, crítico e criativo. O Pedagógico busca instituir o 
sentido para as ações educativas e as características necessárias às escolas/IES para cumprirem seus propósitos e sua intencionalidades.

Propósitos e intencionalidades educativas realizam-se quando se abandona a visão tradicional, técnica e burocrática do currículo e se adota uma mentalidade crítica e reflexiva sobre o papel da educação na sociedade, o que significa ensinar e aprender, bem como uma visão integrada e sistêmica de conhecimento. Isso implica encarar currículo basicamente como um processo (sua característica é essencialmente dinâmica) de construção social do conhecimento, a partir das experiências socioculturais dos sujeitos, ou seja, por meio de espaços intersubjetivos que deixam aflorar os significados culturais que os alunos atribuem aos diferentes objetos, no estudo dos saberes científicos (COIMBRA, 2006), conforme pode ser visto no quadro a seguir:

\begin{tabular}{|l|}
\hline \multicolumn{1}{|c|}{ Perspectiva Crítica e globalizada do Currículo } \\
\hline $\begin{array}{l}\text { O Currículo é centrado na problematização, na inquietação intelectual e na curiosidade } \\
\text { científica. }\end{array}$ \\
\hline $\begin{array}{l}\text { O professor é o mediador entre o conhecimento e o aluno, intervém no processo de aprendizagem } \\
\text { ao criar situações desafiadoras e vinculadas às experiências de vida dos alunos.. }\end{array}$ \\
\hline $\begin{array}{l}\text { O aluno é visto e tratado como sujeito da educação, tem um postura ativa e usa suas experiências } \\
\text { e seus conhecimentos prévios para aprender e se desenvolver. }\end{array}$ \\
\hline $\begin{array}{l}\text { O Conhecimento como instrumento para a compreensão realidade e possível de intervenção nela. } \\
\text { Ė constituído de partes articula e interconectadas das que constituem a totalidade da realidade. }\end{array}$ \\
\hline $\begin{array}{l}\text { O conteúdo é visto dentro de um contexto que dê sentido aos alunos, são vivos e ligados ás } \\
\text { realidades e contextos sociais. }\end{array}$ \\
\hline $\begin{array}{l}\text { Há flexibilidade no uso do tempo e do espaço escolar. A sequenciação do conteúdo é vista em } \\
\text { termos de nível de aprofundamento e metas a alcançar. }\end{array}$ \\
\hline $\begin{array}{l}\text { O Método de ensino baseia-se fundamentalmente em uma análise global da realidade. Propõe } \\
\text { atividades socializadas com metas abertas, permitindo que os alunos estabeleçam suas próprias } \\
\text { estratégias de aprendizagem, as quais são otimizadas mediante atividades motivadoras e } \\
\text { instigantes. }\end{array}$ \\
\hline A Aprendizagem é vista como interação, como apropriação ativa do conhecimento. \\
\hline O ensino é visto como uma construção social.
\end{tabular}

Quadro 1 - Concepção contemporânea de Currículo

Para Pimenta (2002) é possível considerar a ciência de modo diferente, em que o método seja, inicialmente, determinado pelo campo disciplinar com sua lógica interna própria e a clareza de seus determinantes, seus conceitos, leis e princípios, sua historicidade e seu processo de produção. Isso significa dizer que a concepção de conhecimento preside a definição da prática pedagogica realizada na universidade, este conhecimento é importante para ultrapassar a análise simplista realizada apenas sobre as regras didáticas. Compreender que o ensinar e o aprender estão alicerçados numa concepção de mundo e de ciência facilitou uma visão mais global e elucidátiva, especialmente numa época em que a supremacia da ciência tem sido amplamente reconhecida. 
Nessa perspectiva é impossível falar de ensino indissociado da pesquisa, porque, para caminhar na perspectiva globalizada, o ensino tem de incorporar os processos metodológicos investigativos. Nesse particular é importante ressaltar que não há pesquisa sem dúvida, sem questão, sem problema e, estas, só nascem da leitura de como o campo científico se instala na prática, na realidade. Na lógica tradicional do currículo, esta prática, quando existe, está sempre colocada ao final da trajetória acadêmica, impedindo completamente o estudante de aprender através de suas dúvidas epistemológicas, que gerariam um ensino com pesquisa, tendo a extensão como ponto de partida e de chegada do conhecimento produzido.

A seguir, será apresentada uma proposta didática capaz de pôr em prática o dispositivo legal vigente para os cursos de contabilidade que sinaliza as competências e habilidades que os profissionais devem possuir para o exercício de suas atividades.

\section{ENSINO COM PESQUISA COMO PROPOSTA METODOLÓGICA PARA A FORMAÇÃO DE CONTADORES GLOBALIZADOS}

Toda e qualquer proposta de educação traz implícita ou explicitamente uma concepção de homem e de mundo, isto é, são os aspectos filosóficos que dão à educação seu sentido e seus fins. A filosofia, sendo a reflexão sistemática sobre o homem e sobre a concepção da vida, está em estreita conexão com a Pedagogia, que é a reflexão sistemática sobre o ideal da educação e da formação humana (LIBÂNEO, 2001).

Nessa última década, especialmente após a promulgação da LDB/1996, acompanham-se as reformas curriculares que buscam a melhoria da qualidade de ensino, conclama-se cada vez mais que as ações dos alunos se dêem a partir de e sobre a realidade, tanto experiencial cotidiana quanto referente ao futuro exercício profissional, instalando-se assim, a associabilidade entre a construção de conhecimentos pela investigação como determinante para a construção de competências.

A formação de contadores globalizados capazes de responder aos desafios que o mundo thes coloca, depende da construcão de Projeto Político Pedagógico (PPP) para o curso de Ciências Contábeis e da elaboração de currículos globalizados que tomem como princípio metodológico o ensino pela pesquisa. Este se apresenta como o modelo mais adequado ao atual cenário econômico, cultural e político vigente. Busca-se, com essa proposta, o que Doll Junior (2002) ressalta quando diz que um dos desafios educacionais do mundo pós-moderno é planejar um currículo que tanto acomode quanto dimensione; um currículo que (combinando termos e conceitos de Kuhn e de Piaget) tenha a tensão essencial entre o desequilíbrio e o equilíbrio, para que emerja um novo equilíbrio mais abrangente e transformador.

Assim, neste estudo, defende-se um currículo para a área contábil que seja capaz de provocar conflitos cognitivos e questionamentos procedimentais necessários à aprendizagem, portanto, definido como um conjunto de atividades de aprendizagem necessárias para a investigação, argumentação e construção de conhecimentos que possibilitem a autonomia cognitiva, de modo que a realidade seja apreendida e não somente reproduzida; será um passo para uma educação emancipatória e construtiva e, nesse âmbito, o ensino de Contabilidade por certo será diferente.

Aemergência de um novo paradigma na educação contábil e a aderência às novas tendências epistemológicas que determinam outras formas de conceber e representar 
a realidade exige o desapego ao modelo franco-napoleônico que caracteriza o ensino nas IES brasileiras e a adesão ao modelo de formação integral e humanista do individuo, ao invés da formação meramente profissional, voltada para o mercado de trabalho. Acredita-se que uma sociedade com cidadãos formados cientificamente tem maiores condições de avançar econômica, social e culturalmente.

O ensino com pesquisa é uma proposta para o enfrentamento da sociedade do conhecimento e do conhecimento em rede é uma reação a um ensino conservador advindo do modelo napoleônico, que perdura como única forma de ensinar na universidade. A didática ora proposta pode tornar-se realidade e, como proposta inovadora, poderá introduzir novas metodologias e tecnologias e trazer benefícios para a melhoria da qualidade do ensino e das IES.

Assim sendo, trata-se de uma nova postura em relação ao processo de ensinoaprendizagem, que implica problematizar a realidade e mobilizar para a ação conjunta, na busca de soluções para problemas de relevância social e profissional formulados por professores e alunos. Assim, produzir conhecimento, nessa direção, tem o significado de promover um processo permanente de trocas, não aceitando como acabados ou como fim em si mesmos os conteúdos trabalhado nas IES.

Considerar que os conteúdos devam ser contextualizados significa estarem relacionados com as experiências de vida dos alunos, ligados à realidade, local, regional e global. Um ensino criativo motiva e desperta para a investigação. Desse modo, adotar uma metodologia que desperte a curiosidade e a indagação, evitando, assim, o dogmatismo, as certezas absolutas e a estabilidade e se caracterize por despertar a inquietude e a constante busca do saber, poderá contribuir com a qualidade que, durante este trabalho, foi defendida.

A pesquisa, em geral, caracteriza-se por utilizar os conceitos, as teorias, a linguagem, as técnicas e os instrumentos com a finalidade de dar respostas aos problemas e interrogações que se apresentam nos mais diversos âmbitos de trabalho. Demo (1997) considera a dúvida e a indagação a base para o educar pela pesquisa e isso implica uma transformação do entendimento da palavra aprender, que passa do memorizar para o aprender com significado e, desse modo, construir conhecimentos. Nessa concepção de didática, supera-se o conceito de ensinar como instruir, treinar e domesticar e incentiva o construir conhecimento, o mediar processos de aprendizagens significativas e, dessa forma, desenvolve o senso crítico, a postura científica e a autonomia do aluno.

Isso significa propor uma mudança tanto no papel do aluno quanto do professor, que deixa de ser o único detentor e transmissor do conhecimento para ser mediador entre o conhecimento e o aluno, desafiador, interventor com postura de pesquisador. Entendido como um profissional crítico e reflexivo, domina sua área de ensino e os saberes da docência (ANASTASIOU E PIMENTA, 2002). O aluno deixa de ser um simples receptor de informações para se tornar um aprendiz ativo coparticipante do processo de construção do seu conhecimento.

Cunha (1992, p. 18-19) afirma que "é preciso recomeçar, experimentar, ousar, sistematizar, discutir, registrar. Só assim, aos poucos, construiremos um novo conhecimento sobre o ensinar e o aprender de uma forma mais criativa, livre e produtiva". O ensino com pesquisa é uma forma de ensinar o aluno a entender o processo investigativo e a manusear suas ferramentas e métodos em busca de soluções para os problemas que vivencia, o que propicia conhecimento da realidade de forma contextualizada. Para o professor, a pesquisa, além de torná-lo um pesquisador, pode representar fonte inesgotável de produção de novos conhecimentos e transformações, bem como capacidade para questionar e refletir sobre a sua prática que, sem dúvida, trará grandes benefícios tanto para o seu saber-fazer com para a melhoria do ensino do qual é responsável. 
Diferentes autores (DEMO, 1997; LAMPERT, 2008; Cunha, 1992; MORIN, 2005, LIMA, 2004; FREIRE, 1992) salientam a importância do ensino com pesquisa e ponderam que a sala de aula pode se tornar um ambiente de pesquisa. Para tanto, o professor deverá criar atividades de aprendizagem nas quais o aluno utilize de forma sistemática alguns dos pressupostos básicos do ato de pesquisar. Para Lima (2004), esses pressupostos estão ligados a procedimentos metodológicos, tais como: questionamentos, argumentação, produção de textos e reflexão constante sobre a prática. Nesse âmbito, a problematização é vital para a construção do conhecimento e pode significar um potente instrumento de qualificação formal e política do processo educativo A argumentação visa instrumentalizar o aluno com elementos capazes de fundamentar determinadas ideias ou de demonstrar determinado conteúdo. A produção escrita representa a possibilidade e o aluno aprender a posicionar-se como autor e produtor do seu próprio material, bem como reconstruir os já existentes. A discussão e a interação por meio dos textos produzidos constituem-se em fóruns de discussões e interações, de troca de experiências e de aprendizagens colaborativas. Selecionar conteúdos relacionados com as experiências de vida dos alunos e diferentes vivências do cotidiano é um dos princípios essenciais da educação pela pesquisa e é essencial para a compreensão da realidade. Para Lima (2004, p. 168), a pesquisa em sala de aula:

É uma das opções capaz de dar conta de orientar os educandos em seus planos de vida e, ao mesmo tempo, consolidar valores de cidadania, qualificando, deste modo, o sujeito para viver na sociedade contemporânea. Eleger a pesquisa como princípio didático e, antes de tudo, comprometer-se com os pressupostos acima citados, sendo esta decisão, ao mesmo tempo, decorrência de uma série de escolhas que o professor realiza ao organizar a prática docente, tendo por base suas crenças sobre o modo como os alunos aprendem.

Essas ideias e discussões permitem dizer que escolher a educação pela pesquisa é criar espaços efetivos para o aluno questionar, argumentar e escrever entrelaçando conteúdos escolares e realidade, num processo que visa à realização da aprendizagem com a qualidade formal e política, da qual necessita para a qualidade da sua formação profissional.

Nesse sentido, a abordagem didática do ensino estabelece outro tipo de relação entre professor e o aluno, nessa postura metodológica, o professor e o aluno são sujeitos do ato de aprender; o plano é horizontal e não vertical como costuma acontecer (professor que sabe e aluno que retém conhecimento) são sujeitos ativos, autônomos, que num processo contínuo questionam discursos, conceitos, princípios, realidades, por meio da construção de argumentos que possam reconstruir verdades até então aceitas como universais. Essa postura desperta no aluno o senso crítico, a atitude reflexiva e o espírito científico e questionador e, assim, a capacidade de construir argumentos e comunicar resultados (LAMPERT, 2008).

Por outro lado, o aluno desenvolverá competências, habilidades e valores ligados ao ato de pesquisar pela vivência do processo de pesquisa, tais como: Problematizar, encontrar caminho metodológico para a resolução da problemática, criar instrumentos, coletar e interpretar informação, inferir sobre os dados; produzir relatórios de pesquisa etc. Além disso, a referida metodologia favorecerá o desenvolvimento da autonomia do aluno; o trabalho individual e grupal; o trabalho cooperativo; a autopercepção e a autoestima; o conhecimento de si próprio; a superar limitações; a discutir, argumentar e defender ideias; a refletir sobre a sua própria aprendizagem; a navegar no desconhecido; a aprofundar conhecimentos; a ter a capacidade de enfrentar desafios e a construir, de forma contextulizada, um saber, um saber-fazer e um saber- ser, conforme propõem Jacques Delors (2003) em seu livro publicado pela UNESCO “Educação: um tesouro a descobrir”. 
As discussões até aqui realizadas, tiveram a intenção de fundamentar o conceito de pesquisa em sala de aula e de ensino com pesquisa como princípio metodológico no ensino superior que este estudo defende. Entende-se como pesquisa em sala de aula:

Um movimento dialético, em espiral, que se inicia com o questionar dos estados do ser, fazer e conhecer dos participantes, construindo-se a partir disso novos argumentos que possibilitem atingir novos patamares desse ser, fazer e conhecer, estágios esses que estão comunicados a todos os participantes do processo (MORAES, et al. 2002, p. 11)

Segundo esse conceito, o ensino com pesquisa é um conjunto de atividades de aprendizagem e situações desafiadoras e motivadoras da aprendizagem, na qual professor e aluno são sujeitos do ato de aprender, isto é, são sujeitos do processo, na perspectiva da formação de profissionais; cidadãos críticos, capazes de entender e transformar a realidade na qual estão inseridos. Nesse sentido, "aprender com pesquisa é um processo interativo e dialógico que envolve a problematização do conhecimento, a construção de argumentos e sua respectiva validação" (LAMPERT, 2008, p. 12).

A pesquisa, nesse sentido, é vista como forma sistemática e organizada de "diálogo crítico e criativo com a realidade" (DEMO, 1996, p. 128). Assim sendo, não há como pensar em pesquisa sem considerar os sujeitos do conhecimento como protagonistas, sem os quais não se demarca avanço significativo algum, como saber emancipatório, não apenas disciplinar, fragmentado, linear, com tentativas de neutralidade. Pela pesquisa, pesquisadores, sejam eles docentes, discentes ou a própria comunidade, retiram da realidade elementos para interpretá-la, compreendêla e transformá-la.

\subsection{ETAPAS DE UM PROJETO DE INVESTIGAÇÃO EM SALA DE AULA}

O estudo de Latorre e Gonzáles (1992): “O professor investigador: a investigação em sala de aula" e de Lampert (2008) fornecem subsídios capazes de orientar as etapas de uma proposta metodológica com os fundamentos e principios até apresentados. Para Latorre e Gonzáles (1992, p. 8), investigar "en aula es un processo mediante el cual los maestros pueden deliberar sobre su tom de decicisiones y mejorar su práctica docente". Para os autores, uma proposta de ensino com pesquisa abrange distintas etapas que vão desde como iniciar? Como encontrar as informaçãoes? Como planejar as hipóteses, como registrar as informações, como interpretá-las, como e a quem comunicar e refletir sobre o próprio projeto.

Lampert (2008), com base em Latorre e Gonzáles (1992), apresenta a seguintes etapas inter-relacionadas de um projeto de investigalção em sala de aula: questionamento, argumentação e comunicação.

a) Afase da dúvida e da ingação: Aexistência da dúvida é a primeira premissa à construção da argumentação. A indagação refere-se aos conhecimentos dos alunos sobre valores, ética, cultura etc.. Essas reflexões contribuirão na formação de conceitos, de princípios, de atitudes, de habilidades, de valores, de concepções de vida etc.. O questionamento e a dúvida são mais importantes que respostas prontas e acabadas;

b)A fase da argumentação como operação discursiva do pensamento: A argumentação é uma variedade discursiva com a qual se pretende 
defender uma opinião e a partir dela persuadir ou convencer um interlocutor mediante provas ou motivos que estão relacionados ao objeto da argumentação. Nessa fase,os alunos, usando diferentes fontes de consulta, deverão buscar em jornais, revistas, livros, relatórios, internet, por meio do diálogo, de entrevistas com pessoas especializadas ou, ainda, mediante experimentos e informações para equacionar a problematica em questão. Segundo estas informações, o aluno deverá organizar suas ideias; interpretar, analidsar e avaliar os dados para emitir juizos e dar respostas confiáveis ao seu questionamento. Entretanto, as inferências e conclusões são provisórias, pois o conhecimento, é dinâmico e provisório. Na etapa da argumentação, o aluno tem a possibilidade de relacionar teoria/prática, elaborar argumentos fundamentos capazes de dar respostas aos seus questionamentos;

c) A comunicação dos resultados: Essa fase constitui a cuminância do processo de ensino com pesquisa. Nesse momento, o aluno, por meio de diferentes procedimentos (seminários, painel, exposição dialogada, produção de artigo, elaboração de relatório, comunicação em congresso, a próría sala de aula), terá a possibilidade de comunicar os resultados do seu trabalho. Nela, o aluno aprenderá a se comunicar quer de maneira oral ou escrita, a se comunicar de forma clara, sequencial, objetiva e fundamentada, o que auxilirá na formação de sua personlidade. 0 aluno deverá apresentar os resultados de forma oral e escrita, pois estará exercitando e aprofundando na habilidade de escrever, imprescindível na sociedade moderna.

Conforme o que já se discutiu neste texto e o que os autores propõem, a investigação, em sala aula, estimula o debate, desperta a criatividade e a reflexão, assenta-se na busca do conhecimento pelos alunos e pelos professores. Nessa direção, Paulo Freire (1992, p. 192) argumenta que:

(...) toda docência implica pesquisa e toda pesquisa verdadeira implica docência. Não há docência verdadeira em cujo processo não se encontre a pesquisa como pergunta, como indagação, curiosidade, criatividade. (...) não há ensino sem pesquisa e nem pesquisa sem ensino.

Como se pode perceber no decorrer deste texto, a inovação encontra clima favorável, tanto na educação como na sociedade de um modo geral. Segundo Perez Serano (1990), a inovação pode ser fruto da investigação e manifestar-se por meio da modificação dos métodos, das técnicas, dos procedimentos e das estruturas e mudanças de comportamento em determinados grupos, como também pode ser realizada de outras maneiras. O mercado busca profissionais com ampla visão de mundo, com pensamento sistêmico, que não se isolem em especializações que, embora lhes permitam exercer a profissão, negam-lhe a competência exigida pelo mundo do trabalho global. Contadores com consciência crítica e analítica são capazes de atuar não apenas como técnicos, mas como gestores das organizações, de modo a desenvolverem métodos e a manusearem ferramentas que estruturem tomadas de decisões nas diferentes situações profissionais que possam enfrentar.

O ensino com pesquisa é um procedimento metodológico que pode constituirse numa inovação no processo educacional e contribuir de forma significativa para a melhoria da qualidade de ensino na universidade e, em especial, na área Contábil.

Ensinar pela pesquisa nas ciências humanas e sociais, mais especificamente em Administração e Contabilidade, entre outras contribuições esta a "geração de conhecimento sobre o processo de planejamento, organização, acompanhamento e controle que ocorrem em organizaç̃̃es", bem como para "aumentar a eficiência e eficácia” nessas instituições (MATIAS̉-PEREIRA, 2007, p. 29). 
Para o alcance dessa meta, torna-se indispensável a valorização da pesquisa, sua devida importância acontecerá por meio de ações interdisciplinares em que a pós e a graduação atuem em conjunto. A pesquisa, nos cursos de graduação, precisa ser abordada e fomentada de forma sistemática e com caráter teórico-prático, sendo entendida como passo inicial e essencial para que o aluno desenvolva uma postura cientifica e um pensamento crítico: "aprende-se pesquisa pesquisando, quanto antes ela iniciar maior probabilidade de seu sucesso" (AZZI, 1994, p.77). Quanto à investigação no âmbito da pós-graduação, concorda-se com Saviani (1991) que diz que, nos programas lato sensu, a pesquisa assume o papel de mediação para que o ensino, elemento definidor, seja alcançado. Em contrapartida, nos programas stricto sensu, o ensino garante os requisitos para que a pesquisa, elemento definidor seja atingido. Pensar ações conjuntas é a maior prova de aprendizado pela pesquisa.

\section{CONSIDERAÇÕES FINAIS}

Este artigo teve como objetivo aprofundar as discussões e ressaltar o debate em torno das mudanças curriculares e da qualidade do ensino superior, para desse modo, apontar o modelo e a prática curriculares capazes de orientar o trabalho educativo na área Contábil, com vistas a possibilitar aprendizagens significativas no contexto do curso e atender às reais necessidades dos alunos em consonância com as exigências sociais e educacionais contemporâneas. Como dados significativos destaquem-se:

a) a pesquisa como a principal função da universidade pode conduzir a aprendizagens significativas, à inovação e à melhoria da qualidade do ensino superior. A postura indagadora como característica fundamental dos investigadores contemporâneos fomentará a inovação mediante a modificação dos métodos, das técnicas, dos procedimentos que provocarão mudanças nas estruturas e comportamentos nos diferentes campos de sua atuação.

b) A ciência como possibilidade de produção do conhecimento surge para dar respostas ao homem às múltiplas perguntas e provas que a natureza propõe. As reformas curriculares apostam nas dimensões essenciais da pesquisa, quais sejam: analisar a realidade; explicar os acontecimentos; prevenir acontecimentos e controlar intervenientes que atuem sobre ela. Em vista da formação para a ciência e a tecnologia, as reformas, no campo do currículo, cada vez mais, apostam em propostas didáticas nas quais as ações dos alunos se deem a partir de e sobre a realidade, tanto experiencial cotidiana quanto referente ao futuro exercício profissional, evidenciando que a indissociabilidade entre ensino e investigação como princípio didático para pôr em prática o dispositivo legal vigente que sinaliza as competências e habilidades que os profissionais devem possuir para o exercício de suas atividades profissionais.

c) Na direção da abertura para o pensamento sistêmico e complexo caminha a construção do Projeto Político-pedagógico, essa é uma tarefa necessária à efetivação de um processo de formação de profissionais-cidadãos, construtores de conhecimentos e não apenas reprodutores e especialistas. A construção desse projeto não pode prescindir da percepção critica da função social da Universidade e do compromisso político e ético do trabalho docente, nem da discussão epistemológica e da análise crítica dos paradigmas que orientam os processos de seleção, organização, construção e socialização dos conhecimentos nas várias situaçõ̃es de ensino e aprendizagem.

d) $O$ ensino com pesquisa, como um conjunto de atividades de aprendizagem 
e situações desafiadoras, provoca mudanças no papel do professor e do aluno, que, como sujeitos ativos, também aprendem. Na perspectiva da investigação, o professor e aluno são sujeitos do ato de aprender, sendo essa aprendizagem um processo interativo e dialógico que envolve a problematização do conhecimento, a construção de argumentos e sua respectiva validação.

e) 0 ensino com pesquisa é um procedimento metodológico que pode constituirse numa inovação no processo educacional e contribuir de forma significativa para a melhoria da qualidade de ensino na universidade e, em especial, na área Contábil. Contadores com consciência crítica e analítica são capazes de atuar não apenas como técnicos, mas como gestores das organizações, de modo a desenvolverem métodos e a manusearem ferramentas que estruturem tomadas de decisões nas diferentes situações profissionais que possam enfrentar. Isso vem ao encontro das necessidades da Ciência Contábil que precisa superar os limites impostos pelo paradigma dominante e pelos modelos epistemológicos que não contemplam o movimento, a complexidade e reproduzem uma visão simplista da essência da Contabilidade que não atende as reais necessidades da área que clama por sistemas abertos e complexos e em interação com a contemporaneidade.

As ideias e discussões trazidas para este artigo permitem inferir que escolher a educação pela pesquisa é criar espaços efetivos para o aluno questionar, argumentar e escrever entrelaçando conteúdos escolares e realidade, num processo que visa à realização da aprendizagem com a qualidade formal e política, da qual necessita para a qualidade da sua formação profissional. Espera-se que este trabalho contribua para uma ampliação das discussões e estudos sobre a gestão universitária, mais especificamente, a construção do PPP na área Contabilidade e para a emergência de caminhos que conduzam a inovações metodológicas e à implementação de políticas que atendam às reais necessidades dos alunos e possibilitem aprendizagens significativas no contexto universitário.

Futuras pesquisas poderão ser desenvolvidas a partir de temáticas como: a) quais são as crenças, atitudes e saberes do professor que atuem no curso de Ciências Contábeis? b) Como estão sendo vistas e tratadas questões referentes aos conceitos de flexibilidade e autonomia da universidade e que constituem o ideário da qualidade da educação implementado pela nova LDB (1996)? c) Quais são as dificuldades e desafios vivenciados pelos professores dos cursos de Ciências Contábeis diante do atual processo de convergência, no Brasil, com as Normas Internacionais de Contabilidade, o qual cobra novo perfil profissional e, neste contexto, um novo perfil de educador, no qual a formação dos professores se configura como elemento vital?

\section{REFERÊNCIAS}

ALARCÃO, Isabel. Professores reflexivos em uma escola reflexiva. 2.ed. São Paulo: Cortez, 2003.

ASSMANN, Hugo. Reencantar a educação: rumo à sociedade aprendente. Petrópolis: Vozes, 1998.

Metáforas novas para reencantar a educação - epistemologia e didática. Piracicaba: Unimep, 2001.

AZZI, Roberta Gurgel. Pesquisa (em psicologia e educação) e a universidade: alguns pontos para reflexáo. In: Revista Pro-Pro - posições. Campinas, v. 5, 13, p. 77-85, mar. 1994. 
BRASIL. Lei de Diretrizes e Bases, da Lei no 9.394/96, de 20 de dezembro de 1996.

Câmara de Educação Superior/ Conselho Nacional de Educacão CES/CNE, $583 / 2001$. Orientação para as diretrizes curriculares dos cursos de graduação. DF: MEC, 2001.

Conselho Nacional de Educação / Câmara de Educação Superior ${ }_{2}$ CES/ CNE. Diretrizes Curriculares Nacionais dos cursos de graduacão em Direito, Ciências Econômicas Administração, Ciências Contábeis, Turismo, Hotelaria, Secretariado Executivo, Música, Dançá, Teatro e Design. Brasília, DF: MÉC, 2002.

CATANI, A. M. et al. Política educacional, mudanças no mundo do trabalho e reforma curricular dos cursos de graduação no Brasil.' Educação e Sociedade. v. 22, 75, Campinas, 2001.

Cervo, A. BerVIAN, P. Metodologia Científica. 5.ed. São Paulo: Prentice Hall, 2002.

CHAUÍ, Marilena. Universidade em ruínas. In: Hélgio TRINDADE (org.). Universidade em ruínas na República dos Professores. Petrópolis/Porto Alegre,' Vozes/Cipede, 1999. ed. da UNESP, 2001.

Escritos sobre a universidade. São Paulo: Faculdade de Filosofia e Ciências,

CHAVES, A. O ciclo de formação geral e a reforma do ensino superior. [2007]. Disponível em: http: / / www.educacao.gov.br/reforma/Documentos/ARTIGOS/2005.3.7.17.4.56. pdf. Acesso em: 30 mar. 2007.

CUNHA. Maria Isabel da. O ensino com pesquisa. In: Cadernos de educação, Pelotas, 1.p. 17-19 dez. 1992.

Paradigmas científicos e propostas curriculares. In: Revista Interface Comunicação em saúde, Educ. 2, 1998.

COIMBRA, Ivanê Dantas. Educação contemporânea e currículo Escolar: alguns desafios. In: Candombá - Revista Virtual', v. 2, 2, p. 67-71, jul - dez 2006. Disponivel em: http: / i www. fja.edu.br/candomba/2006-v2n2/pdfs/lvaneDantasCoimbra2006v2n2.pdf> Acesso em: 07de julho de 2010.

DAGOSTIM, Salézio. Reestruturando o Ensino da Contabilidade para o Século XXI. Brasília: CFC, 2000.

DELORS, Jacques. Educação: Um tesouro a descobrir. 8.ed, São Paulo: Cortez, Brasilia, DF:MEC, UNESCO', 2003.

DEMO, Pedro. Pesquisa e Construção de Conhecimento - Metodologia científica no caminho de Habermas. Tempo Braśileiro, Rio de Janeiro. 1994.

. Pesquisa: Princípio científico e educativo. 4.ed. Cortez, 1996.

- O desafio de educar pela pesquisa na educação básica. In: Educar pela pesquisa. 2.ed. Campinas: Autores Associados, 1997.

DIAS SOBRINHO, J. (Org.); RISTOFF, Dilvo (Org.) ; GOERGEN, Pedro (Org.) . Universidade e Sociedade: perspectivas internacionais. Sorocaba: EDUNINSO, 2008. v. 1.

DIAS SOBRINHO, José. Dilemas da Educação Superior no Mundo Globalizado: Sociedade do Conhecimento ou Economia do Cónhecimento? São Paulo: Casa do Psicólogo, 2005.

Cambios y reformas en la educación superior. In: Carlos Tünnermann (Org.). La educación superior en América Latina y el Caribe: diez años espues de la Conferencia Mundial de 1998. 1 ed. Cali; Caracas: Pontificia Universidad Javeriana/IESALC-UNESCO, 2008, v. 01, p. 95-140. 
Educação superior, globalização e democratização: o debate ético-político. In: Denise Leite. (Org.). Avaliação participativa e quálidade: os atores locais em foco. 1.ed. Porto Alegre: Sulina; Editora Universitária Metodista, 2009, p. 33-55.

DOLL JR. , W. Ghosts and the curriculum. In: DOLL JUNIOR, W. e GOUGH, Noel (Orgs. ). Curriculum Visions. New York: Peter Lang. 2002. pp. 23-70.

DOURADO, L. F; CATANI. A. M. OLIVEIRA, J. F. Política educacional, mudanças no mundo do trabalho e reforma curricular dos cursos de graduação no Braşil. In: Educação e sociedade, Campinas - SP, p. 67-83, 2001.

FAZENDA, I. C. A. Interdisciplinaridade: um projeto em parceria. 5.ed. São Paulo: Loyola, 2002.

FERNANDES, M. R. Mudança e Inovação na Pós-Modernidade. Perspectivas curriculares. Porto: Porto Editora. 2000.

FREIRE, Paulo. Pedagogia da Esperança: um reencontro com a Pedagogia do Oprimido. São Paulo: Paz e Terra, 1992.

GADOTTI, Moacir. Interdisciplinaridade: atitude e método. São Paulo: In: Instituto Paulo Freire. Disponivel: <www.paulofreire.org>. Acesso em: 26 dez. 2006.

GOMES GOMES, Sonia Maria da Silva, et al. Uma análise dos projetos políticopedagógicos dos cursos de Ciências Contábeis das Universidades Públícas do Estado da Bahia. In: Revista Brasileira de Contabilidade, n. 178, julho/agosto de 2009.

HARGREAVES, Andy. O Ensino na sociedade do conhecimento - educacão na era da insegurança. Trad. Roberto Cataldo Costa. Porto Alegre: Artemed, 2004.

IUDÍCIBUS, Sérgio; MARION, José C. Introdução à teoria da contabilidade para o nível de graduação. São Paulo: Átlas, 1999.

KINCHELOE, J. A formação do professor como compromisso político: mapeando o pós-moderno. Porto Alegre: Artes Médicas, 1997.

KUENZER, A. Z. O que muda no cotidiano da sala de aula universitária com as mudancas no mundo do trabalho? In: CASTANHO, S; CASTANHO, M. E. (Org.) Temas e textos em metodologia do ensino superior. São Paulo: Papirus, 2001.

KUHN, T. S. The Structure of Scientific Revolutions. 2.ed., Enlarged. Chicago and London: University of Chicago Press 1970.

LAMPERT, Ernani. 0 ensino com pesquisa; realidade, desafios e perspectivas na universidade brasileira. In: Revista on line Linhas Críticas, Brasília, v. 14, 26. P. 5-24, jan/jun.2008. Disponível em: http://www.fe.unb.br/linhascriticas/artigos/n26/o_ensino.pdf > Acesso em: 26 jun. 2010.

LATORRE, Antonio; GONZALEZ, Romana. El maestro investigador: la investigación em el aula. 2.ed. Barcelona: Grao, 1992.

LEITE, D. \& MOROSINI, M. Universidade no Brasil: a idéia e a prática. Revista Brasileira de estudos pedagógicos. Brasília - DF, mai/ago, 1992.

LIBANEO, J. C. Organização e Gestão da escola: teoria e prática. Goiânia: Alternativa, 2001.

LIMA, Licínio C. O paradigma da educação contábil: Políticas educativas e perspectivas gerencialistas no ensino superior em Portugal. In: Trabalho apresentado na XIX Reunião Anual da ANPEd, Caxambu, setembro de 1996. Disponível em: http://www.anped.org. br/rbe/rbedigital/RBDE04/RBDE04_06_LICINIO_C_LIMA.pdf >Acesso em: 17 jun. 2010.

MACHADO, Lucília. A institucionalização da lógica das competências no Brasil. ProPosições, Campinas. Vol. 13, 1, 37, p.' 92-110, 2002.

MARION, J. C. O ensino da contabilidade. São Paulo: Atlas, 1996. 
MASETTO, Marcos Tarciso. Competência pedagógica do professor universitário. São Paulo: Summus, 2003.

MINISTÉRIO DA EDUCAÇ̃̃O, Conselho Nacional de Educação. Parecer $n^{\circ}$ CES/ CNE 0146/2002, de 03 de abril de 2002. Disponível em: http://jporfiro.spaces.live.com/blog/ cns!AAE6C1C1F59A1C42!169.entry >Acesso em: 20 jun. 2010.

MINISTÉRIO DA EDUCAC̃̃̃O, Conselho Nacional de Educação. Resolução CNE/CES 10/2004, de 16 de dezembro de 2004. Disponível em: http:// www.mec.gov.br/cne. Acesso em: 20 jun. 2010.

MORAES, Maria Cândida. O paradigma educacional emergente: implicações na formação do professor e nas práticas pedagógicas. In: Em Aberto, Brasília, ano 16, 70, abr./jun. 1996.

MOREIRA, A. F . B. ; CANDAU, V. M. Indagações sobre currículo: currículo, conhecimento e cultura, Brasília: Ministério da Educaçã̃o, Secretaria de Educação Básica, 2007.

MORIN, Edgar. A cabecca bem-feita: repensar a reforma, reformar o pensamento. Rio de Janeiro: Bertrand Brasil, 2001. Cortez, 2005.

Educação e complexidade, os sete saberes e outros ensaios. São Paulo:

NOSSA, V. Ensino da contabilidade no Brasil: uma análise crítica da formacão do corpo docente. Dissertacão (Mestrado em Ciências Contábeis) - Faculdade dé Economia, Administração e Contabilidade da Universidade de São Paulo, FEA/USP. São Paulo, 1999.

PADOAN, F. A. C., CLEMENTE, A. A interdisciplinaridade no ensino da Contabilidade: um estudo empírico da percepcão dos docentes. In: CONGRESSO USP,DE CONTROLADORIA E CONTABILIDADE, 6, 2006, São Paulo. Anais eletrônicos... Disponivel em http: / / www. congressoeac.locaweb.com.br/artigos62006/551.pdf. Acesso em: 10 jan. 2007.

PAIVA, S. B. O ensino da Contabilidade: em busca da interdisciplinaridade. In: Revista Brasileira de Contabilidade, Brasília, v. 28, 120, p. 89-93, 1999.

PASSOS, I. C. A interdisciplinaridade no ensino e na pesquisa contábil: um estudo no município de São Paulo, 2004. Dịssertação (Mestrado em Controladoria e Contabilidade) - Faculdade de Economia, Administração e Contabilidade, Universidade de São Paulo, São Paulo, 2004.

PIMENTA, S. G. \& ANASTASIOU, L. G. C. Docência no ensino superior. São Paulo: Cortez, 2002. (Coleção Docência em formação).

PEREZ SERRANO, M. G. Investigación-acción. Aplicaciones al campo social y educativo. Madrid: Dykinson, 1990.

PIMENTA, S. G. \& ANASTASIOU, L. G. C. Docência no ensino superior. São Paulo: Cortez, 2002. (Coleção Docência em formação).

RICCIO, Edson L; SAKATA, Mariçi C. G. Evidências da Globalização na Eduçação Contábil: estudo das grades curriculares dos cursos de graduação em universidades brasileiras e portuguesas. In: Revista Contabilidade e Finanças - USP. São Paulo: FEA/ USP, 35, p. 35 - 44, mai/ago, 2004.

ROZA, J. P. Apesquisa no processo de formação de professores: intenções e experiências docentes e discentes e as limitações deste exercício - um olhar sỏb duas realidades educacionais. Dissertação (Mestrado em Educação) - Programa de Pós Graduação em Educação, Universidade Federal do Rio Grande do Sul, Porto Alegre, 2005.

SAVIANI, D. Concepções da dissertação de Mestrado centrada na idéia de monografia de base. In: Revistá Educação Brasileira, Brasília, v.13, 27, p. 159-168, 1991.

SAVIANI, Dermeval. Pedagogia Histórico-crítica: primeiras aproximações. 8.ed. São Paulo: Cortez; Autores Associados, 2003. (Coleção polêmicas do nosso tempo; v. 40). 
SOUSA SANTOS, B. A gramática do tempo: para uma nova cultura política. São Paulo: Cortez, 2006.

SAVIANI, Demerval. Histórias das idéias pedagógicas no Brasil. Campinas: Autores Associados, 2007.

TALÍZINA, N. F. Psicologia de la enseñanza. Moscou: Editorial Progresso, 1988.

TRINDADE, Hélgio. (Org.) et al. Universidade em ruínas - na república dos professores. Petrópolis: Vozes, 1999.

TRUJILLO, N. R. Selección efectiva de personal basada em competencias. In: Revista do Serviço Público. v. 51, 3, p. 101-121, jul./set., 2000.

VEIGA, Ilma Passos A. (Org.) Projeto Político-Pedagógico: uma construção possível. 17.ed. Campinas: Papirus, 2004.

\section{ENDEREÇO DOS AUTORES:}

\section{Vilma Geni Slomski}

Fundação Escola de Comércio Álvares Penteado

Av. Liberdade, 532 - Liberdade

São Paulo, SP - Brasil

01502-001

\section{Antonio Carlos Ribeiro da Silva}

Universidade do Estado da Bahia,

Centro de Educação Técnica da Bahia

Rua Silveira Martins - Cabula

Salvador, BA - Brasil

42000-000

\section{Sonia Maria da Silva Gomes}

Universidade Federal da Bahia

Endereço: Praça 13 de Maio, 6 - Centro

Salvador, BA Brasil

CEP.: 40070-010

\section{Isac Pimentel Guimarães}

Universidade Federal da Bahia

Endereço Rua Politeama de Baixo, nº 69 Centro,

Apto. 606, Bloco B, Politeama

Salvador, BA Brasil

40080-166 